\title{
Bitcoin ile Finansal Makro Değişkenler Arasındaki İlişki: Türkiye Üzerine Bir Var Analizi
}

\author{
The Relationship Between Bitcoin and Financial Macro Variables: A Var Analysis On Turkey \\ Hüseyin İşcan a,* \\ a Doktora Öğrencisi, Süleyman Demirel Üniversitesi, İktisadi ve İdari Bilimler Fakültesi, İktisat Bölümü, 32200, Isparta/Türkiye. \\ ORCID: 0000-0002-3121-4007.
}

\section{MAKALE BİLGISI}

\section{Makale Geçmişi:}

Başvuru tarihi: 04 Ocak 2020

Düzeltme tarihi: 14 Temmuz 2020

Kabul tarihi: 20 Temmuz 2020

Anahtar Kelimeler:
Bitcoin
Döviz kuru
Borsa İstanbul Endeksi
Faiz oranı

\section{ARTICLE INFO}

\section{Article history:}

Received 04 January 2020

Received in revised form 14 July 2020

Accepted 20 July 2020

\section{Keywords:}

Bitcoin

Exchange rate

Borsa İstanbul Index

Interest rate
ÖZ

Bu çalışmada amaç; Bitcoin, döviz kuru, Borsa İstanbul Endeksi ve faiz değişkenleri arasındaki ilişkileri Türkiye için 2013:11-2019:10 dönemi haftalık verileri kullanarak incelemektir. Çalışmada VAR modeli kurularak değişkenler arasındaki uzun dönem ve nedensellik ilişkileri araştırılmış, etki-tepki grafikleri ve varyans ayrışım tablosuyla analiz sonuçlandırılmıştır. Çalışma sonucunda Bitcoin ile diğer değişkenler arasında uzun dönemde herhangi bir eşbütünleşme ilişkisi ve nedensellik ilişkisi tespit edilememiş, ancak diğer değişkenlerin kendi aralarında nedensellik ilişkileri saptanmıştır. Etki-tepki grafiklerine göre Bitcoin'e verilen bir şoka döviz kuru üç haftalık negatif tepki göstermiş diğer haftalarda verilen tepki anlamsız olmuştur. Türkiye'de kripto paralar üzerinde belirli bir farkındalığın olduğu ancak bu farkındalığın uzun vadeli yatırım boyutunda ve makro değişkenleri etkileyebilecek güçte olmadığı görülmektedir. Türkiye'de yeni sayılabilecek olan bu teknolojinin yaygınlaşabilmesi için belirli bir zamana ihtiyaç vardır.

\section{A B S T R A C T}

The aim of this study, the relations between Bitcoin, exchange rate, Stock Exchange Istanbul index and interest rate variables are to examine using weekly data for the period 2013:11-2019:10 for Turkey. In the study, by establishing a VAR model, long-term and causality relationships between variables were investigated, and analysis was concluded with effect-response graphs and variance decomposition table. As a result of the study, there was no long-term correlation and causation relationship between Bitcoin and other variables; however, causation relations between the other variables were determined. According to the impact-response charts, the exchange rate reacted negatively to a shock to Bitcoin for three weeks, and the response in other weeks was meaningless. It is seen that there is on crypto coins in Turkey a certain awareness, but this awareness there is not in long-term investment dimension and there is not strong enough to affect macro variables. It needs some time to spread the technology, which can be considered new in Turkey.

\section{Giriş}

Geçmişten günümüze kadar alışverişlerde farklı ödeme yöntemleri kullanılmıştır. Hayatın dinamiği içinde mevcut ödeme araçlarının işlevinin yitirmesiyle yeni ödeme yöntemleri geliştirilmiştir. Trampa ekonomisiyle başlayan bu süreç yerini madeni paralara oradan kağıt paralara ve artık günümüze gelindiğinde ise daha çok kartlara ve elektronik ödeme araçlarına bırakmıştır. Yaşanan her değişim zaman ve işlem maliyetlerini düşürmekte hayatı daha da kolaylaştırmaktadır. Bu konuda en son gelinen nokta ise kripto para olarak ifade edilen sanal paralardır.

Kripto para olarak tarif edilen sanal para Avrupa Merkez Bankasının tanımlamasına göre "geliştiricileri tarafından ihraç edilen ve belirli bir sanal çevre tarafından kontrolü sağlanan, regülasyonu olmayan bir dijital paradır" (European Central Bank (ECB), 2012: 13) şeklinde tanımlamıştır. Başka bir tanımlamaya göre: “dijital olarak değiş tokuş edilebilen, hesap birimi ve değer saklama işlevlerini yerine getirebilen fakat herhangi bir yasal

* Sorumlu yazar/Corresponding author

e-posta: huseyn.can17@yahoo.com 
sağlayıcı sahipliği statüsü olmayan paradır" (The Financial Action Task Force (FATF), 2014: 4). Kripto paralar herhangi bir otorite tarafindan kontrol edilmeyen, herhangi bir aracı kurumun olmadığı, merkezi olmayan bir sistemdir. $\mathrm{Bu}$ paralar kriptoloji yani șifreleme bilimini kullanan, matematik temelli şifrelenmiş dijital para birimi olarak bilinmektedir (Nair ve Motwani, 2018: 36). Kripto paralarda değer içeren her türlü yapı bloklarda saklanmakta burada tamamlanan bloklar birbiri ardına bir zincir halkası gibi eklenerek blokchaini oluşturmaktadır. Blockchain kayıtları herkese açık, şeffaf, dağıtık ve sıralı dijital kayıtlardır. Blockchain teknolojisinin temel bileşenleri; bilgisayarlardan oluşan bir eșten eşe ăg , bu ağda iletișimi yönetecek belirli bir mutabakat mekanizmasıdır (Durbilmez ve Türkmen, 2019: 31).

Kripto paraların yüksek fiyat volatilitesine rağmen trendinin artış yönünde olması bu paralara olan rağbeti artırmıştır. Bu paraların reel piyasada alışveriş işlemlerinde kullanımı yaygın olmamasına karşın kripto para borsalarındaki işlem hacmi özellikle son yıllarda büyük bir artış göstermiştir. $\mathrm{Bu}$ artan taleple birlikte kripto paraların değerlerinde de son beş yıl içerisinde astronomik artışlar yaşanmıştır. $\mathrm{Bu}$ durum birçok yatırımcının kripto paraların kısa ve uzun vadeli ticaretine ilgi duymasının önünü açmıştır (Dağlı, 2019:44).

Coinmarket verilerine göre günümüzde 2354 tane kripto para bulunmakta ve bu sayı her geçen gün artmaktadır. Bu kripto paraların içinde en değerlisi 164 milyar dolar işlem hacmi ile Bitcoin'dir. Bitcoin 2008 y1lında kurucusu olan Satoshi Nakamoto adlı takma isimli kişi ya da kişiler tarafından kurulmuş ve 2009 yılında ilk Bitcoin transferi gerçekleşmiştir. Bitcoin reel ekonomiyle 2010 yılında Laszlo Hanyecz adlı bir kişinin 10.000 Bitcoin karşılığında iki adet pizza satın alarak tanışmıştır. Bu durum Bitcoin ile yapılan ilk alışveriş olmuştur (Koçoğlu vd.,2016: 79). Günümüze gelindiğinde ise Bitcoin'e olan talep her geçen gün artmaktadır. $\mathrm{Bu}$ durum ülkelerin finansal araçları üzerinde spekülatif etkilerde bulunmaktadır. İşlem hacminin büyüklüğü, fiyatındaki volatilitenin yüksek olması, kullanım kolaylığı kendisini cazip kılmaktadır. Bu nedenle Bitcoin ve benzeri kripto paraların finansal piyasalar ile olan etkileşimi iyi analiz edilmelidir.

Kripto paralar bir para birimi olarak kullanılsa da günümüzdeki para birimlerinden faklıdır ve döviz kuru olarak kabul edilmemekte daha çok yatırım aracı olarak kullanılmaktadır. Spekülatif olarak volatilitesi yüksek olan hisse senedine benzemektedir. $\mathrm{Bu}$ nedenle yatırımcıları kendisine çekebilmekte kısa vadede büyük kazançlar sağlayabilmektedir. İlk zamanlarda ödeme araçları olarak hizmet etmesi beklenen kripto paralar yükselen trendiyle zamanla yatırım aracı haline gelmiş bu durum çeşitli kripto borsalarının oluşmasını sağlamıştır. Böylece kısa vadede yüksek kazanç elde etmek isteyen kişi ve firmalar geleneksel yatırım araçları ve borsaların yerine yatırımlarını kripto paralara kaydırmışlardır. Bu nedenle kripto paraların borsalar üzerindeki etkisi araştırmacılar tarafından incelenmektedir.

Uluslararası piyasalarda en güçlü ve en konvertibl para olan doların etkisi son yıllarda özellikle gelişmekte olan ülkelerin para birimlerini etkilemektedir. Doların gücünü son yillarda etkileyebilecek yeni bir mekanizma olarak kripto paralar tartışılmaktadır. Kripto paraların artan trendi geleneksel para birimlerinin geleceğiyle ilgili endişeler uyandırmaktadır. $\mathrm{Bu}$ endişeler kripto paraların, para birimlerini etkileyeceği yönündedir. $\mathrm{Bu}$ durum Merkez Bankalarının para politikalarını gözden geçirmelerine neden olabilmektedir. $\mathrm{Bu}$ nedenle kripto para ile döviz kuru arasındaki ilişkinin ortaya konulması literatüre katkı sağlayacağı düşünülmektedir.

Çalışmada kripto paralar içerisinde aktif büyüklüğü \%40'lara ulaşan Bitcoin, Borsa İstanbul Endeksi, döviz kuru ve faiz arasındaki ilişkiler incelenmiştir. Çalışma giriş ve sonuç bölümleri hariç üç bölümden oluşmaktadır. İlk bölümde kripto paraların gelişimi hakkında bilgi verilmiş, ikinci bölümde bu konuda yapılmış yerli ve yabancı çalışmalara değinilmiş ve son bölümde ekonometrik analiz yapılmıştır.

\section{Blockchain Teknolojisi, Kripto Paralar ve Bitcoin}

Blockchain, taahhüt edilen tüm işlemlerin bir blok zincirinde saklandı̆̆ 1 bir kamu defteridir. Bu zincir, yeni bloklar eklendiğinde sürekli olarak büyümektedir. Blockchain teknolojisi, ademi merkeziyetçilik, kalıcılık, anonimlik ve denetlenebilirlik gibi temel özelliklere sahiptir. Blockchain, kriptografik şifreleme, dijital imza ve dağıtılmış ağ mekanizması gibi çeşitli çekirdek teknolojilerin entegre edilmesiyle etkinleştirilen merkezi olmayan bir ortamda çalışmaktadır (Zheng vd.,2018: 354).

Blockchain teknolojisi, bankalar, kredi kuruluşları, hükümetler ve muhasebeciler gibi aracılar tarafindan merkezi olarak kontrol edilen geleneksel veri tabanları yerine dağıtılmış defterleri kullanarak dijital varlık işlemlerinin kayıtlarını tutan eşler arası (P2P) bir ăgdır. Merkezi olmayan, açık ve kriptografik yapısı güveni beraberinde getirir ve böylece benzeri görülmemiş güvenlik avantajları sağlar. Blockchain tüm işlemleri takip edebildiğinden, bankalar gibi büyük merkezi aracıları yaygın olarak etkileyen saldırıları neredeyse imkânsız hale getirecektir. Bir kişi Blockchain'de belirli bir bloğa saldırmak isterse, kişi bu blokun yanı sıra o blok zincirinin tüm geçmişindeki önceki blokları hacklemesi gerekir. Bu nedenle blockchain teknolojisi, ticari faaliyetlerin ve işlemlerin güvenli bir şekilde oluşturmanın bir yolunu sağlamaktadır (Fallahpour, vd., 2014; Lemieux, 2016; Min, 2019: 2). Blockchain ve benzeri kripto para birimleri, kullanıcıların birbirlerine güvenmelerini sağlayacak bir arabulucuya ihtiyaçları yoktur; daha çok güven, merkezi olmayan ağ sisteminin içinde kendini gösterir. Blockchain böylece ideal "Güven Makinesi" paradigması gibi görünmektedir (Miraz \& Ali, 2018: 3).

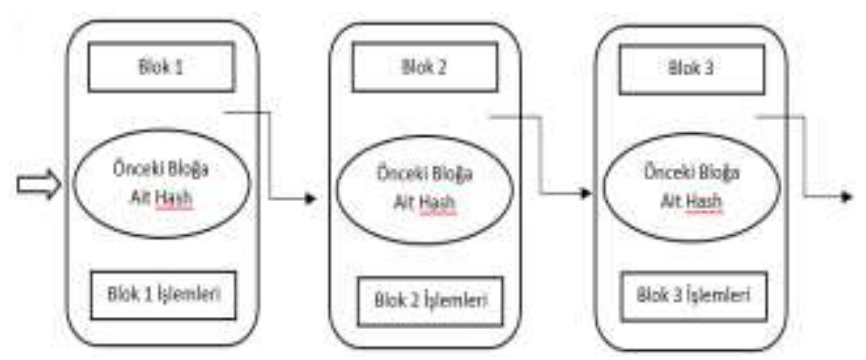

Şekil 1. Blok zincir yapısı (Khalilov vd., 2017:3). 
Kripto para birimleri dağıtık sistemlerdir. Bu paralar, sahteciliği önlemek, işlemleri ve arzı kontrol etmek için kriptografi kullanırlar. İşlemler, onaylandıktan sonra, dijital olarak saklanır. $\mathrm{Bu}$ işlemler şekil 1 de görüldüğü üzere muhasebe sistemi olarak düşünülebilecek bir blok zincir içine kaydedilir. Bu zincir herkese açık ve erişilebilir olarak tutulmakta ve yapılan tüm işlemleri içermektedir (Gandal \& Halaburda, 2014'den aktaran, Karaoğlan vd., 2018: 14).

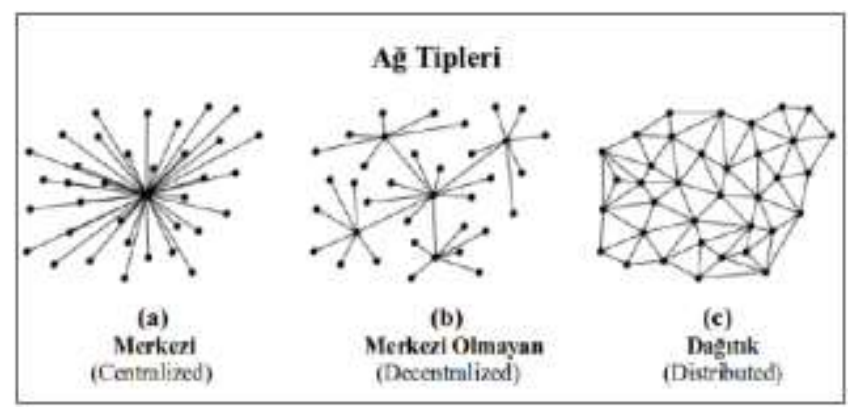

Şekil 2. A ̆g tipleri (Çarkacıŏ̆lu, 2016: 13).

Cyripto ve currency kelimelerinin birleşmesiyle oluşan şifreli para anlamına gelen kripto paralar (Turan, 2018:2), şekil 2'deki merkezi olmayan, dağıtık ă̆ sistemini kullanırlar. Kripto paralar, katılımcılar arasındaki işlemleri doğrulamak için ortak anahtarlı şifreleme ve işlemsel bütünlüğü sağlamak için dijital imzaları kullanır. Bir kripto para birimi sisteminde, ortak anahtar katılımcının hesap numarası olarak kabul edilebilirken, özel anahtar katılımcının kimlik bilgilerini temsil eder. Tüm katılımcıların özel anahtarları saklamak için kullanılan dijital cüzdanların yanı sıra katılımcıların sahip olduğu kripto para birimi haklarını (paraları) temsil eden dijital imzaları vardır. Cüzdanlar, katılımcının gereksinimlerine bağlı olarak özel olarak veya web sitelerinde veya borsalarda çevrimiçi olarak saklanabilmektedir. (Herbert \& Litchfield, 2015: 28).

Bitcoin, temel olarak blockchain teknolojisine bağlı en popüler kripto paradır. 2008 yılında kurucusu olan Satoshi Nakamoto adlı takma isimli kişi ya da kişiler tarafindan kurulmuş olan Bitcoin "Bitcoin: Uçtan Uca Elektronik Ödeme Sistemi"(Bitcoin: A peer to peer electronic cash system) isimli makaleyle tüm dünyaya duyurulmuştur (Nakamoto, 2008). Bitcoin "BTC" olarak kısaltılmaktadır. Para biriminin en küçük değerine satoshi denilmektedir. Bu da bir Bitcoin'in 100 milyonda birine eşittir (0.00000001 BTC) ve ismini Bitcoin'in yaratıcısı olan Satoshi Nakamoto'ya saygidan dolayı "satoshi" olarak adlandırılmaktadır. Blok zincirindeki tüm miktarlar, diğer para birimlerine dönüştürülmeden önce satoshi cinsinden yer almaktadır. Kaynak kodu, Bitcoin miktarını belirtirken satoshi kullanmaktadır (kriptokoin.com).

Bitcoin, merkezi olmayan küresel ağdaki bilgisayarların işlemcileri çalıştırılarak üretilmektedir. Açık kaynak kodlu madenci yazılımının devreye girmesiyle, Bitcoin ağına dâhil olan herkes madenci olabilmekte ve Bitcoin arzı yaratabilmektedir. Bitcoin'ler, madencilik (mining) ad1 verilen, transfer işlemleriyle uğraşırken karmaşık bir matematik problemini, birbirleriyle yarışarak çözen, madenciler aracılığıyla arz edilir. Problemi çözen madenci belli miktar Bitcoin ile ödüllendirilir. Her dört y1lda bir madencilere verilen ödül $\% 50$ oranında azaltılır ve yıllar geçtikçe problem daha da zorlaşır. (Çarkacıoğlu, 2016: 13).
Her dört yılda bir gerçekleşen madencilere verilen ödülün yarıya indirilmesine halving denir. Günümüzde kadar üç kere gerçekleşen halving, sırasıyla 2012, 2016 ve en son 2020 yılının Mayıs ayında gerçekleşmiştir. Bitcoin arzı 21 milyonla sınırlı tutulmuştur. Coindesk (2020), verilerine göre su ana kadar 18 milyon Bitcion arz edilmiştir. Bu, yaklaşık 120 yıl içinde sıfırlanacak olan sürekli azalan, Bitcoin arz1 anlamına gelmektedir. 120 y1l sonra yani 2140 yılında son Bitcoin'in çıkarılmasıyla madencilere sadece 1 Satoshi, yani 0,00000001 BTC ödül verilecek. Bu noktadan itibaren artık blok ödülü verilmeyecektir (investing.com).

\section{Kripto Paraların Gelişimi}

Kripto paraların teorik anlamdaki altyapısı 1998 yılında Wei Dei tarafindan "b-money" konsepti olarak oluşturulmuştur (Dai, 1998). 1999 yilında Milton Friedman internetin hükümetin rolünü azaltacak büyük güçlerden biri olacağını ve dijital paraların tüm dünya yayılacağının kaçınılmaz olduğunu ifade etmiştir (Andersson ve Wegdell, 2014: 8). 2005 yılında Vishnumurthy ve arkadaşları "karma" adını verdikleri peer to peer (P2P) çalışma prensibiyle çalışan çevrimiçi para birimi oluşturmuşlardır. Ancak küresel çapta tek para birimi yaratmak isteseler de bunda başarılı olamamışlardır (Vishnumurthy vd, 2005). 2008 yılına gelindiğinde Bitcoin'in de kurucusu olan Satoshi Nakamoto takma isimli bir kişi ya da grubun çalışmaları sonucu kripto paralar dünya genelinde yaygınlaşmaya başlamıştır. $\mathrm{Bu}$ sistem de yine önceki yaratılan sistem gibi peer to peer yani iki taraflı elektronik ödeme sistemiyle aynı prensibe sahiptir (Nakamoto, 2008).

Bitcoin ilk kez 9 Ocak 2009'da Windows işletim sistemlerinde, $\mathrm{C}++$ yazılım diliyle açık kaynak olarak yayınlanmıştır. Alfa sürüm olan ilk versiyonunun duyurulmasının ardından 12 Ocak 2009'da Nakamoto, Hal Finney'e Bitcoin transfer etmesiyle ilk işlem gerçekleşmiştir. 2010 yılında Swiftcoin adıyla çıkan altcoin borç senedi işlemleri takas etmek için kurulmuş ve bu özelliğiyle Amerika Patent ve Marka Ofisinden ilk patent almıştır. 2011 yılında Litecoin, ilk scrypt özetleme algoritmasını kullanmıştır (Çeker, 2018: 5). 2012 yılında piyasaya sürülen Ripple diğer kripto paraların aksine blockchain teknolojisini kullanmamaktadır. "Merkezi olmayan bir mutabakat protokolüne dayanmasina rağmen, Ripple'ın mevcut dağılımı Ripple Laboratuvarları tarafindan yürütülmektedir." Kurumsal bir merkeze sahip olması nedeniyle ödeme sistemleri sağlayıcısı banka ve şirketlerin tercih ettiği bir kripto para ve transfer sistemi olmasını sağlamıştır (Aslan,2018: 10). Ethereum, 2013 yılının sonlarında Vitalik Buterin tarafından tasarlanmış daha sonra İsviçre merkezli Ethereum Vakfi tarafından finanse edilmiş ve resmi olarak 2015 yılında piyasaya sürülmüştür. Ethereum, Bitcoin'e göre daha gelişmiş Ethash isminde bir algoritma kullanmakta ayrica kendi tuning-complete programlama dilini kullanmaktadır (Kesebir ve Günceler: 616). 2014 yılında kurulan Tron Singapur menşeili blok zincir tabanlı açık kaynak kodlu merkezi olmayan bir kripto paradır. Yine bir başka kripto para olan Tether ise Tron ve diğer paralar gibi açık kaynak kodlu bir kripto paradır. Tether değerini 1 tether $=1$ dolar olacak şekilde sabitlemeye çalışmaktadır. Binance coin ise kripto para borsası Binance'nin ürettiği bir kripto paradır. 
2017 yllinda kurulan EOS ise yine merkezi olmayan blockchain tabanlı bir sistemdir (Coin-türk, 2019).

Tablo 1. Dünya Piyasalarındaki En Büyük 10 Kripto Para

\begin{tabular}{ccc}
\hline İsim & Fiyat (Dolar) & $\begin{array}{c}\text { Piyasa Değeri(Milyar } \\
\text { Dolar) }\end{array}$ \\
\hline Bitcoin & $9.251,4$ & 164,71 \\
Ethereum & 183,1 & 19,63 \\
Ripple & 0,2944 & 12,67 \\
Bitcoin Cash & 286,64 & 5,07 \\
Tether & 1.004 & 4,13 \\
Litecoin & 59,005 & 3,71 \\
Binance Coin & 19,98 & 3,10 \\
EOS & 3,29 & 3,04 \\
Bitcoin SV & 131,66 & 2,33 \\
Tron & 0,02 & 1,3 \\
https://tr.investing.com/crypto/currencies & Erişim & Tarihi \\
\hline Kaynak: & &
\end{tabular}

Tablo 1'de görüldüğü üzere Bitcoin 164 milyar dolar piyasa değeri ile en yüksek hacimli kripto para konumundadır. Diğer kripto paralar ise Bitcoin'in altcoinleridir. Bitcoin'e alternatif olarak çıkarılan bu altcoinlerin ortaya çıkmasıyla kripto paralar tabana yayılmıştır. Bunlar genel kullanım amacından ziyade daha çok özel işlemlere yönelik üretilmekte ve kripto para piyasasında Bitcoin'in türevleri olarak gösterilmektedir (Ateş,2016: 360).

Bitcoin ve diğer altcoinler finansal piyasaları derinden etkilemiştir. Günün her saati işlem yapma imkanı, düşük komisyon düzeyleri, para gönderimi ve işlem hızı gibi avantajları sayesinde geleneksel aracı kurumlara üstünlük sağlamıştır (Karaoğlan vd.2018: 16).

\section{Literatür Taraması}

Konuya ilişkin literatür Tablo 2'de sunulmuştur.

Tablo 2. Literatür Özeti

\begin{tabular}{|c|c|c|c|c|}
\hline Yazarlar ve tarih & Dönem & Yöntem & Değişkenler & Sonuç \\
\hline Atik vd. (2015) & $2009-2015$ & Granger nedensellik testi & $\begin{array}{l}\text { Bitcoin, } \\
\text { farklı } \\
\text { birimi }\end{array}$ & $\begin{array}{l}\text { Japon Yen'i ile Bitcoin arasında nedensellik olduğu } \\
\text { saptanmış olup Japon Yen'i ile Bitcoin birbirlerini } \\
\text { gecikmeli olarak etkilemektedir. }\end{array}$ \\
\hline $\begin{array}{l}\text { Georgoula vd. } \\
\quad(2015)\end{array}$ & $2014-2015$ & $\begin{array}{l}\text { Vsm Model, Vecm } \\
\text { Model }\end{array}$ & $\begin{array}{l}\text { Bitcoin, } \\
\text { S\&P500 } \\
\text { Endeksi, Twiter } \\
\text { duyarlılık oranı, } \\
\text { Wikipedia } \\
\text { arama oranları }\end{array}$ & $\begin{array}{l}\text { Twitter duyarlılık oranı ile Bitcoin fiyatları arasında pozitif } \\
\text { korelasyon varken kısa dönem analizde Wikipedia arama } \\
\text { sorgularının sayısının Bitcoin'lerin fiyatı üzerinde olumlu } \\
\text { bir etkiye sahip olduğu tespit edilmiştir Uzun dönemli } \\
\text { analizde Bitcoin fiyatı ile dolaşımdaki Bitcoin sayıs } \\
\text { arasında pozitif kolerasyon saptanırken, S\&P500 endeksi } \\
\text { arasında negatif ilişki belirlenmiştir. }\end{array}$ \\
\hline $\begin{array}{l}\text { Chu, Nadarajah } \\
\text { ve Chan (2015) }\end{array}$ & 2011-2014 & $\begin{array}{l}\text { En popüler } 15 \text { parametrik } \\
\text { dağ } 1 \text { lım }\end{array}$ & Bitcoin, USD & $\begin{array}{l}\text { Bitcoin kurları çok karmaşık dinamikler sergilemektedir. } \\
\text { Bitcoin yatırımı yüksek getiriye sahip olup aynı zamanda } \\
\text { yüksek oynaklık sergilemektedir. }\end{array}$ \\
\hline $\begin{array}{l}\text { Kristoufek } \\
(2015)\end{array}$ & 2011-2014 & Wavelets yöntemi & $\begin{array}{l}\text { Bitcoin, USD ve } \\
\text { Çin yuanı }\end{array}$ & $\begin{array}{l}\text { Çin Bitcoin piyasası ile USD Bitcoin piyasası arasında } \\
\text { nedensellik ilişkisine rastlanmamıştır. }\end{array}$ \\
\hline Song (2016) & 2011-2016 & $\begin{array}{l}\text { Vecm Model, Linear } \\
\text { Regresyon Model, } \\
\text { Eşbütünleşme Testi }\end{array}$ & $\begin{array}{l}\text { Bitcoin, USD, } \\
\text { Borsa } \\
\text { Endeksleri }\end{array}$ & $\begin{array}{l}\text { Uzun dönemde döviz kurları ile Bitcoin fiyatları arasında } \\
\text { eşbütünleşme ilişkisi tespit edilmiştir. Ayrıca, borsa } \\
\text { endeksleri ile Bitcoin fiyatları arasında pozitif ilişkinin } \\
\text { varlığı da saptanmıştır. }\end{array}$ \\
\hline
\end{tabular}

$\begin{array}{ll}\text { (2016) } & \text { Euro, Ruble }\end{array}$
kıyasla çok daha fazla olduğu ayrıca, Bitcoin ile belirtilen para birimleri arasında herhangi bir anlamlı ilişki tespit edilememiştir.

\begin{tabular}{|c|c|c|c|c|}
\hline $\begin{array}{l}\text { Dyhrberg } \\
(2016)\end{array}$ & $2010-2015$ & GARCH Modeli & $\begin{array}{l}\text { Bitcoin, Ons } \\
\text { Altın ve USD }\end{array}$ & $\begin{array}{l}\text { Bitcoin ile altın ve doların hedging ve değişim aracı } \\
\text { işlevlerinin birbirine benzediğini bu nedenle, Bitcoin'in } \\
\text { risk yönetimi ve riskten kaçınmak isteyen yatırımcılar için } \\
\text { kullanışlı olabileceği belirtilmiştir. }\end{array}$ \\
\hline $\begin{array}{l}\text { Szetela, vd. } \\
\text { (2016) }\end{array}$ & $2014-2016$ & $\begin{array}{lll}\text { ARMA ve } & \text { GARCH } \\
\text { Modelleri } & \end{array}$ & $\begin{array}{l}\text { Bitcoin, } 4 \text { farklı } \\
\text { para birimi }\end{array}$ & $\begin{array}{l}\text { Bitcoin, analizde yer alan tüm para birimlerinden bağımsız } \\
\text { bir şekilde hareket etmektedir. }\end{array}$ \\
\hline $\begin{array}{l}\text { Katsiampa } \\
(2017)\end{array}$ & $2010-2016$ & $\begin{array}{lll}\text { ARCH } & \text { ve } & \text { GARCH } \\
\text { Modeli } & & \end{array}$ & $\begin{array}{l}\text { Bitcoin günlük } \\
\text { kapanıș fiyatları }\end{array}$ & $\begin{array}{l}\text { ARCH-GARCH modelinin Bitcoin'in fiyat oynaklığ } 1 \\
\text { tahmini için uygun modeller olduğu tespit edilmiştir. }\end{array}$ \\
\hline $\begin{array}{l}\text { Klein vd. } \\
(2018)\end{array}$ & $2011-2018$ & BEKK-GARCH Modeli & 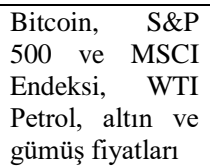 & $\begin{array}{l}\text { Bitcoin'nin aşağı yönlü pazarlarla olumlu bir şekilde } \\
\text { ilişkili olduğu tespit edilmiştir. Bitcoin'nin gelecekteki } \\
\text { gelişimi belirsiz olduğundan fiyatlarında her iki yönde } \\
\text { dalgalanmaların olacağı tahmin edilmiştir. }\end{array}$ \\
\hline $\begin{array}{l}\text { Baur, vd. } \\
(2018)\end{array}$ & $2010-2017$ & GARCH Modeli & $\begin{array}{l}\text { Bitcoin, Ons } \\
\text { Altın ve USD }\end{array}$ & $\begin{array}{l}\text { Bitcoin ile altın ve dolar arasında bir ilişki tespit } \\
\text { edilememiştir. }\end{array}$ \\
\hline $\begin{array}{l}\text { Çütçü ve Kılıç } \\
\text { (2018) }\end{array}$ & $2013-2018$ & $\begin{array}{lr}\text { Maki } & \text { Eşbütünleşme } \\
\text { Testi, Hacker-Hatemi-J } \\
\text { Bootstrap } \quad \text { Nedensellik } \\
\text { Testi }\end{array}$ & $\begin{array}{l}\text { Bitcoin, Dolar } \\
\text { Kuru }\end{array}$ & $\begin{array}{l}\text { Dolar kuru ile Bitcoin fiyatları arasında orta ve uzun } \\
\text { dönemde eşbütünleşme ilişkisi tespit edilmiştir. Ayrıca } \\
\text { dolar kurundan Bitcoin fiyatlarına doğru tek yönlü } \\
\text { nedensellik ilişkisi saptanmıştır. }\end{array}$ \\
\hline
\end{tabular}




\begin{tabular}{|c|c|c|c|c|}
\hline $\begin{array}{l}\text { Çütçü ve Kılıç } \\
\qquad(2018)\end{array}$ & $2012-2018$ & $\begin{array}{ll}\text { Engle-Granger } & \text { ve } \\
\text { Gregory-Hansen } & \\
\text { eşbütünleşme testleri } & \text { ile } \\
\text { Toda-Yamamoto } & \text { ve } \\
\text { Hacker-Hatemi-J } & \\
\text { nedensellik testleri } & \end{array}$ & $\begin{array}{l}\text { Bitcoin, BİST } \\
100 \text { Endeksi }\end{array}$ & $\begin{array}{l}\text { Bitcoin fiyatları ile BİST100 endeks değeri arasında orta ve } \\
\text { uzun vadede bir eşbütünleşme ilişkisi tespit edilememiştir. } \\
\text { Toda-Yamamoto nedensellik testine göre BIST100 } \\
\text { endeksinden Bitcoin fiyatlarına doğru tek yönlü } \\
\text { nedensellik ilişkisi saptanmıştır. }\end{array}$ \\
\hline Yildırım (2018) & $2012-2013$ & $\begin{array}{l}\text { Johansen eşbütünleşme } \\
\text { testi }\end{array}$ & $\begin{array}{l}\text { Bitcoin, ons } \\
\text { altin }\end{array}$ & $\begin{array}{l}\text { Uzun vadede altın fiyatları bitcoin fiyatlarını etkilemekte } \\
\text { iken tersi durum geçersizdir. }\end{array}$ \\
\hline $\begin{array}{l}\text { Kanat ve Öget } \\
\quad(2018)\end{array}$ & 2013-2018 & $\begin{array}{l}\text { Johansen eşbütünleşme } \\
\text { testi, Granger nedensellik } \\
\text { testi }\end{array}$ & $\begin{array}{l}\text { Bitcoin, G7 ülke } \\
\text { borsaları }\end{array}$ & $\begin{array}{l}\text { Bitcoin ile ülke borsaları arasında uzun vadede bir ilişki } \\
\text { tespit edilememiştir. Kısa vadede ise İngiltere borsası } \\
\text { bitcoinin nedeni, bitcoinin ise S\&P ve Kanada borsasının } \\
\text { nedeni olduğu saptanmıştır. }\end{array}$ \\
\hline $\begin{array}{l}\text { İçellioğlu ve } \\
\text { Öztürk (2017) }\end{array}$ & 2013-2017 & $\begin{array}{l}\text { Johansen eşbütünleşme } \\
\text { testi, Granger nedensellik } \\
\text { testi }\end{array}$ & $\begin{array}{l}\text { Bitcoin, } \\
\text { gelen } 5 \text { farklı } \\
\text { birimi }\end{array}$ & $\begin{array}{l}\text { Kısa ve uzun vadede Bitcoin ile ilgili para birimleri } \\
\text { arasında herhangi bir ilişki saptanmamıştır. }\end{array}$ \\
\hline $\begin{array}{l}\text { Ağan ve Aydın } \\
\quad \text { (2018) }\end{array}$ & $2013-2018$ & Hatemi-J nedensellik testi & 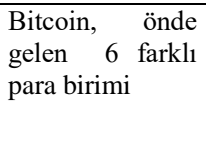 & $\begin{array}{l}\text { Bitcoin ile Yen, Yuan, Kanada Doları ve Amerikan Doları } \\
\text { arasında tek yönlü şokların etkisine rastlanırken; Euro ve } \\
\text { İngiliz Sterlini arasında tek veya çift yönlü bir nedensellik } \\
\text { ilişkisine rastlanmamıştır. }\end{array}$ \\
\hline $\begin{array}{l}\text { Güleç, Çevik ve } \\
\text { Bahadır (2018) }\end{array}$ & 2012-2018 & $\begin{array}{l}\text { Johansen eşbütünleşme } \\
\text { testi, Granger nedensellik } \\
\text { testi }\end{array}$ & $\begin{array}{l}\text { Bitcoin, dolar } \\
\text { kuru, } \\
\text { fiyatları, BİST } \\
100 \quad \text { endeksi, } \\
\text { faiz }\end{array}$ & Bitcoin'in faizin nedeni olduğu sonucuna ulaşılmıştır. \\
\hline $\begin{array}{l}\text { Topaloğlu } \\
\text { (2019) }\end{array}$ & $2012-2017$ & $\begin{array}{l}\text { Gregory-Hansen } \\
\text { eşbütünleşme testi ve } \\
\text { Granger nedensellik testi }\end{array}$ & $\begin{array}{l}\text { Bitcoin, } 8 \text { farkll } \\
\text { para birimi }\end{array}$ & $\begin{array}{l}\text { Uzun vadede Bitcoin ile diğer döviz kurlart arasında } \\
\text { eşbütünleşme ilişsisi tespit edilmiştir. Nedenselliğin yönü } \\
\text { ise Çin Yuanı'ndan Bitcoin'e doğrudur. }\end{array}$ \\
\hline
\end{tabular}

\section{Ekonometrik Analiz}

Çalışmada Türkiye için Bitcoin, dolar kuru, Borsa İstanbul Endeksi ve faiz değişkenleri arasındaki ilişkiler zaman serileri yardımıyla analiz edilmiştir.

\subsection{Kapsam ve Veri Seti}

Çalışmada Türkiye için 2013:11-2019:10 dönemi haftalık veriler kullanılarak Bitcoin Fiyatları, dolar kuru, Borsa İstanbul Endeksi ve faiz değişkenleri kullanılmıştır. Bitcoin Fiyatlar1 https://tr.investing.com/ sitesinden, dolar kuru, Borsa İstanbul Endeksi ve faiz verileri ise Türkiye Cumhuriyet Merkez Bankası Elektronik Veri Dağıtım Sisteminden (EVDS) alınmıştır. Çalışmadaki verilerin analizinde Ewievs 9 paket programından yararlanılmıştır.

Tablo 3. Veri Tanıtımı ve Kaynakları

\begin{tabular}{ccc}
\hline Değişken & Kisaltması & Kaynak \\
\hline Bitcoin & BTC & https://tr.investing.com/ \\
Borsa İstanbul Endeksi & BİST & TCMB (EVDS) \\
Dolar kuru & DK & TCMB (EVDS) \\
Faiz & R & TCMB (EVDS) \\
\hline
\end{tabular}

Çalışmada değişkenler logaritmaları alınarak modele dâhil edilmiştir. Bu logaritmik dönüşümün yapılma sebebi belirli bir tabana göre logaritmalarının alınarak parametrelerin küçülmesi ve analiz bulgularının yorumlanmasında kolaylık sağlamasıdır. Değişkenlere logaritmik dönüşüm uygulaması verilerde herhangi bir bilgi kaybına neden olmayıp serisel korelasyonun azalmasına ve serilerin normal dağılım göstermesine yarımcı olmaktadır (Dirican ve Canöz, 2017: 383).

\subsection{Ekonometrik Yöntem ve Ampirik Sonuçlar}

Çalışmanın bu bölümünde değişkenlerin aralarındaki ilişkileri belirleyebilmek için ekonometrik test yöntemleri ve ampirik bulgulara değinilmiştir.

Çalışmada serilerin durağanlığını sağlamak için Artırılmış Dickey-Fuller (The Augmented Dickey-Fuller) ve PhillipsPeron birim kök testleri yapılmıştır. Serilerin birinci farkları alınarak seriler durağan hale getirilmiştir. VAR modeli kurularak Johansen eşbütünleşme testi ile değişkenler arasındaki uzun dönem ilişkisi araştırılmış, Blok Granger Nedensellik testi ile değişkenler arasındaki nedensellik ilişkisi saptanmış, en son etki tepki grafikleri ve varyans ayrıştırma tablosu ile analiz sonuçlandırılmıştır.

\subsubsection{Birim Kök Testleri}

İktisatta teorilerin geçerliliği sınanırken ekonometrik test yöntemlerine sıklıkla başvurulmaktadır. Zaman serileri üzerine çalışan araştırmacılar yapılan analizlerin ilk aşamasında serilerin birim kök sürecinde olup olmadığını kontrol etmektedir. Bunun nedeni bir serinin durağan olup olmaması analizin işleyişini etkilemesidir. Dolayısıyla hem iktisadi teorilerin açıklanmasında hem de ekonometri literatüründe bir ön test olarak durağanlık analizi çok önemli bir hale gelmektedir (Mert ve Çağlar, 2019: 97).

Ekonometrik analizlerde değişkenler uzun dönemde birçok şoka maruz kalmaktadır. Serilerin şoklara karşı dirençli olması yani şokların etkisinin geçici olması durağan olduğu, tam tersi şokların etkisinin kalıcı olması durağan olmadığı anlamına gelmektedir. Yani seriye herhangi bir şok verildiğinde uzun dönemde serinin ortalamasında ve varyansında bir değişim meydana gelmiyorsa serinin durağan olduğu anlaşılmaktadır.

Birim kök olup olmadığının tespit edilmesi için kullanılan iki hipotez kullanılmakta olup bunlar şu biçimde gösterilebilir:

- $H_{0}: \delta=0$ (Birim kök vardır, seri durağan dışıdır), 
- $H_{1}: \delta<0$ (Birim kök yoktur, seri durağandır).

Oluşturulan hipotezlerin mevcut model içinde test edilmesi ise şu şekilde olmaktadır:

- Hesap değerinin kritik değerden büyük olduğu durumda $\mathrm{H}(0)$ hipotezi ret edilip ilgili serinin durağan olduğuna karar verilmektedir.

- Olasılık değerinin 0.05 'ten küçük olduğu durumda H (0) hipotezi ret edilip ilgili serinin durağan olduğuna karar verilmektedir.
Serilerin birim kök içerip içermediği Arttırılmıș Dickey Fuller (ADF) ve Phillips-Peron (PP) birim kök testi ile analiz edilmiştir. Testler düzey değerlerinde ve birinci farkları alınarak sabitli ve sabitli + trendli terimler esas alınarak gerçekleştirilmiştir.

Tablo 4'te serilerin düzey değerlerinde durağan olmadiğg, ancak serilerin birinci farkları alındığında hem ADF hem de PP testlerinde durağan olduğu görülmektedir.

Tablo 4. ADF ve PP Birim Kök Testi Sonuçları

\begin{tabular}{|c|c|c|c|c|c|c|c|c|c|}
\hline & & Değişkenler & $\mathrm{ADF}$ & PP & & & Değişkenler & $\mathrm{ADF}$ & PP \\
\hline & & LOGBTC & $-0.37(0)$ & $-0.39(4)$ & & & $\Delta$ LOGBTC & $-18.01(0)$ & $-17.99(5)$ \\
\hline & & & [0.9106] & [0.9067] & & & & {$[0.000]^{*}$} & {$[0.000]^{*}$} \\
\hline & & LOGBİST & $-1.75(0)$ & $-1.68(5)$ & & & $\Delta$ LOGBİST & $-18.54(0)$ & $-18.58(4)$ \\
\hline & $=$ & & {$[0.4030]$} & [0.4399] & & $=$ & & {$[0.000]^{*}$} & {$[0.000]^{*}$} \\
\hline & 墕 & LOGDK & $-0.40(1)$ & $-0.52(8)$ & & ही & $\Delta$ LOGDK & $-14.40(0)$ & $-14.69(7)$ \\
\hline & & & [0.9054] & [0.8843] & 푸 & & & {$[0.000]^{*}$} & {$[0.000]^{*}$} \\
\hline & & LOGR & $-1.71(4)$ & $-1.55(12)$ & $x$ & & $\Delta$ LOGR & $-5.28(3)$ & $-14.40(11)$ \\
\hline : & & & {$[0.4238]$} & [0.5042] & $\frac{1}{5}$ & & & {$[0.000]^{*}$} & {$[0.000]^{*}$} \\
\hline & & LOGBTC & $-1.67(0)$ & $-1.70(3)$ & & & $\Delta$ LOGBTC & $-18.04(0)$ & $-18.04(4)$ \\
\hline & & & [0.7601] & {$[0.7475]$} & & & & {$[0.000]^{*}$} & {$[0.000]^{*}$} \\
\hline & $\overline{0}$ & LOGBİST & $-2.64(0)$ & $-2.68(7)$ & & $\overline{0}$ & $\Delta$ LOGBİST & $-18.51(0)$ & $-18.55(4)$ \\
\hline & 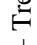 & & [0.2613] & [0.2447] & & 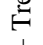 & & {$[0.000]^{*}$} & {$[0.000]^{*}$} \\
\hline & $\stackrel{+}{=}$ & LOGDK & $-2.58(1)$ & $-2.81(8)$ & & $\stackrel{+}{=}$ & $\Delta$ LOGDK & $-14.38(0)$ & $-14.67(6)$ \\
\hline & 㫄 & & [0.2867] & [0.1940] & & 馬 & & {$[0.000]^{*}$} & {$[0.000]^{*}$} \\
\hline & & LOGR & $-2.22(4)$ & $-1.80(12)$ & & & $\Delta$ LOGR & $-5.31(3)$ & $-14.44(11)$ \\
\hline & & & [0.4760] & {$[0.7016]$} & & & & {$[0.000]^{*}$} & {$[0.000]^{*}$} \\
\hline
\end{tabular}

Not: *,** ve *** değerleri \%1, \%5 ve \%10 seviyelerinde anlamlılı̆̆ını ifade etmektedir. Parantez içindeki değerler, ADF için Schwarz istatistik bilgi kriterine; PP için "Barlett Kernel" ve "Newey West bandwith" yöntemine göre uygun gecikme uzunluğunu göstermektedir. Köşeli parantez içindeki değerler olasılık değerlerini göstermektedir.

\subsubsection{Vektör Otoregresif (VAR) Modeli}

Sims (1980), tarafından geliştirilen Vektör Otoregresif Model (VAR) Modeli tek değişkenli otoregresif (AR) modelinin çok değişkenli biçimidir. VAR analizinde, her bir zaman serisinin içsel olarak sisteme dahil edildiği ve zaman serilerinin $\mathrm{p}$ gecikmelerine kadar bağımsız değişkenler olarak alındığı vektörel denklem sistemi tahmin edilmektedir. VAR modelinde amaç parametre tahmini yapmaktan çok zaman serilerinin birbirlerinden nasıl etkilediğini anlamaya çalışmaktır. Bir VAR(p) modelinde katsayıları yorumlamak oldukça güç olmaktadır. Dolayısıyla VAR analizi yapmada temel amaç, zaman serilerine ait etki tepki fonksiyonları, varyans ayrıștırması ya da Granger nedensellik analizi sonuçlarını elde etmek olacaktır. VAR analizindeki temel koşul serilerin durağanlığıdır, eğer seriler farkları alınıp durağanlaştırılırsa, zaman serileri arasındaki etkileșime ait bir kısım veriler kaybolacaktır. $\mathrm{Bu}$ yüzden durağan dişı zaman serileri arasındaki ilişkilerin VAR analizinden çok eşbütünleşme analizleri ile incelenmesi daha doğru olacaktır. Ancak durağan dışı zaman serileri arasında bir eşbütünleşme ilişkisi bulunamazsa, farkları alınıp durağanlaştırılarak VAR analizi ile test edilebilirler (Mert ve Çağlar, 2019: 215).

VAR analizinde ilk yapılması gereken işlemlerden birisi gecikme uzunluğunun belirlenmesidir. Bu modelde tahmin yapılırken p gecikme sayısı olması gerekenden küçük alınırsa parametrelerin tahmini tutarlı olmamakta; eğer olması gerekenden büyük alınırsa da parametrelerin varyansı büyük çıkmaktadır (Kadılar, 2000).

Tablo 5. Gecikme Uzunlukları

\begin{tabular}{lllllll}
\hline Lag & LogL & LR & FPE & AIC & SC & HQ \\
\hline 0 & 52.57346 & NA & $8.46 \mathrm{e}-06$ & -0.328199 & -0.278329 & -0.308232 \\
1 & 2401.921 & 4619.324 & $1.20 \mathrm{e}-12$ & -16.09406 & $\mathbf{- 1 5 . 8 4 4 7 1 *}$ & -15.99422 \\
2 & 2435.843 & 65.78171 & $1.07 \mathrm{e}-12$ & -16.21515 & -15.76633 & $\mathbf{- 1 6 . 0 3 5 4 5}$ \\
3 & 2460.661 & 47.45637 & $1.01 \mathrm{e}-12$ & -16.27474 & -15.62643 & -16.01517 \\
4 & 2476.250 & 29.38651 & $1.01 \mathrm{e}-12$ & -16.27196 & -15.42417 & -15.93252 \\
5 & 2503.413 & 50.47231 & $\mathbf{9 . 3 5 e - 1 3 *}$ & $\mathbf{- 1 6 . 3 4 7 3 8 *}$ & -15.30012 & -15.92808 \\
6 & 2515.664 & 22.43248 & $9.60 \mathrm{e}-13$ & -16.32205 & -15.07531 & -15.82288 \\
7 & 2523.134 & 13.47706 & $1.02 \mathrm{e}-12$ & -16.26442 & -14.81820 & -15.68538 \\
8 & 2530.972 & 13.92766 & $1.08 \mathrm{e}-12$ & -16.20927 & -14.56357 & -15.55036 \\
9 & 2542.774 & 20.65451 & $1.11 \mathrm{e}-12$ & -16.18091 & -14.33573 & -15.44214 \\
10 & 2563.142 & $\mathbf{3 5 . 0 9 3 1 3 *}$ & $1.08 \mathrm{e}-12$ & -16.21042 & -14.16576 & -15.39178 \\
11 & 2565.850 & 4.592288 & $1.18 \mathrm{e}-12$ & -16.12061 & -13.87647 & -15.22210 \\
12 & 2579.755 & 23.20600 & $1.20 \mathrm{e}-12$ & -16.10645 & -13.66284 & -15.12808 \\
\hline
\end{tabular}


Tablo 5'te yıldızla işaretli yerler VAR modeli için uygun gecikme uzunluğunu göstermektedir. VAR modelinde model için uygun istikrar koşullarını bu gecikme uzunlukları sağlayamazsa gecikme uzunlukları artırılabilir. Ancak gecikme uzunluğunun artırılması serbestlik derecesini düşüreceğinden gözlem sayısının az olması gibi durumlarda gecikme sayısının az girilmesinde fayda vardır (Mert ve Çağlar,2019: 222).

VAR analizinde tüm değişkenler içsel olarak sisteme dahil edilmektedir. Ancak serilerin sıralaması özellikle varyas ayrıştırması yaparken önem kazanmaktadır. Bu sıralama içsel değişkenlerden dışsal değişkenlere doğru olmalıdır. Buna teorik olarak karar vermenin yanı sira istatistiksel olarak nedensellik analizleri yaparak da karar verilebilmektedir. İyi bir VAR modeli kurabilmek için belli istikrar koşulları vardır. Bu koşulları sağlamayan VAR modeli, bilgi kriterleri en uygun gecikmeyi vermiş olsalar dahi uygun bir model kurulamayacaktır. VAR modeli için istikrar koşulları üç tanedir. Ters köklerin çemberin içinde olması, serisel korelasyonun olmaması, değişen varyans sorununun olmamasidir.

VAR denklem sisteminde karakteristik köklerin mutlak değerce 1'den küçük olması sistemin durağan değişkenler tarafindan oluşturulduğunu göstermektedir. $\mathrm{Bu}$ durumda karakteristik kökler çemberin içinde yer almakta aksi durumda istikrar koşulu sağlanamamaktadır.

Şekil 3'te görüldüğü üzere karakteristik kökler çemberin içinde yer almaktadır. Böylece VAR modelinin ilk istikrar koşulu sağlanmıştır.

Inverse Roots of AR Characteristic Polynomial

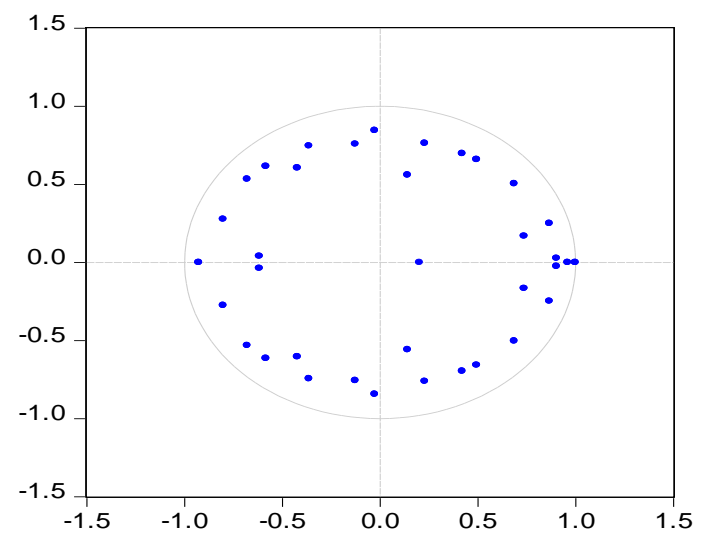

Şekil 3. AR Karakteristik Polinom Ters Kökleri

İkinci varsayım olan serisel kolerasyonun olmaması koşulu Lagrange Çarpanları (Otokolarasyon LM) testi ya da Portmanteau Otokolerasyon testinden faydalanabilmektedir.

Bilgi kriterleri 1, 2, 5 ve 10. gecikmenin uygun gecikme uzunluğunu söylese de bu gecikmelerde otokolerasyon ve değișen sorununa rastlanıldığı için gecikme uzunluğu sorun çözülene kadar artırılmıştır ve 12. Gecikmede otokolerasyon ve değişen varyans sorununun çözüldüğü görülmüştür. Böylece tüm istikrar koşulları sağlanmıştır. Böylece modele VAR (12) üzerinden devam edilecektir.
Tablo 6. Otokorelasyon LM Testi

\begin{tabular}{ccc}
\hline Lag & LM Test İstatistiği & Olasılık Değerleri \\
\hline 1 & 11.10522 & 0.8029 \\
2 & 17.46504 & 0.3561 \\
3 & 16.32109 & 0.4308 \\
4 & 17.66113 & 0.3441 \\
5 & 9.294564 & 0.9008 \\
6 & 16.91635 & 0.3910 \\
7 & 7.777791 & 0.9552 \\
8 & 12.18219 & 0.7313 \\
9 & 21.16226 & 0.1724 \\
10 & 9.075181 & 0.9103 \\
\hline
\end{tabular}

Tablo 7. White Değişsen Varyans Testi

\begin{tabular}{ccc}
\hline \multicolumn{3}{c}{ VAR Residual Heteroskedasticity Tests } \\
\hline Chi-sq & df & Prob. \\
& & \\
2995.574 & 2980 & 0.4168 \\
\hline
\end{tabular}

\subsubsection{Johansen Eşbütünleşme Testi}

Johansen eşbütünleşme testinde, seriler arasında olası denklem sistemleri incelenerek birden fazla eşbütünleşme ya da denge ilişkisi vektörel olarak analiz edilmektedir. Bu amaçla Johansen (1988: 1996), Johansen ve Jeselius (1990) çalışmalarında çoklu denklem yaklaşımı getirip her bir seriyi içsel kabul ederek eşbütünleşme ilişkisini vektörel olarak tanımlamıştır. $\mathrm{Bu}$ analizde denklem sistemindeki serilerin aynı dereceden entegre olması gereklidir. $\mathrm{Bu}$ durumun oluşmaması durumunda analiz uygulanamamaktadır.

Tablo 8. Johansen Eşbütünleşme Testi

\begin{tabular}{cccc}
\hline Yokluk hipotezi & İz istatistiği & .05 kritik değer & prob \\
& & & \\
\hline $\mathrm{r}=0$ & 48.94987 & 54.07904 & 0.1326 \\
$\mathrm{r} \leq 1$ & 29.38934 & 35.19275 & 0.1846 \\
$\mathrm{r} \leq 2$ & 13.40536 & 20.26184 & 0.3323 \\
$\mathrm{r} \leq 3$ & 4.511247 & 9.164546 & 0.3413 \\
\hline Yokluk hipotezi & Max. & .05 kritik değer & prob \\
& Özdeğer & & 0.4465 \\
$\mathrm{r}=0$ & 19.56053 & 28.58808 & 0.2994 \\
$\mathrm{r} \leq 1$ & 15.98397 & 22.29962 & 0.4453 \\
$\mathrm{r} \leq 2$ & 8.894116 & 15.89210 & 0.3413 \\
$\mathrm{r} \leq 3$ & 4.511247 & 9.164546 & \\
\hline
\end{tabular}

Tablo 8'e bakıldığında, hesaplanan iz istatistiği ve maksimum özdeğer istatistiklerinin kritik değerlerle karşılaştırılması sonucunda $\% 5$ anlam düzeyinde herhangi bir eşbütünleşme vektörünün olmadığı görülmektedir. Başka bir ifadeyle, Bitcoin, döviz kuru, BİST 100 ve faiz değişkenleri arasında uzun dönemde herhangi bir eşbütünleşme ilişkisinin olmadığını ifade eden sıfır 
hipotezi, iz ve maksimum özdeğer istatistikleri tarafından kabul edilmiştir.

\subsubsection{Granger Nedensellik Testi}

Ekonometrik olarak nedensellik kavramı Granger (1969) çalışması ile literatüre kazandırılmıştır. Çalışmanın ana düşüncesi bir değişkenin cari dönemdeki değeri açıklanırken başka bir değişkenin gecikmeli değerleri bu değişkenin açıklamasına katkı sağlıyorsa değişkenler arasında bir nedensellik ilişkisi olduğu söylenebilmektedir. Değişkenler arasındaki nedensellik testlerinde dört farklı sonuç ortaya çıkmaktadır (Mert ve Çağlar, 2019: 340).

- $\quad x, y ’ n i n$ Granger nedenidir.

- $\quad y, x^{\prime}$ in Granger nedenidir.

- $\quad x$ ile y arasında Granger nedensellik ilişkisi yoktur.

- $\quad x$ ile y arasında geri besleme süreci vardır (Çift yönlü Granger nedensellik).

Tablo 9. Blok Granger Nedensellik Testi Sonuçları

\begin{tabular}{cccc}
\hline \multicolumn{4}{c}{ Bağımlı değişken: BTC } \\
\hline Excluded & Chi-sq & Df & Prob. \\
LOGBİST & 10.71327 & 12 & 0.5536 \\
LOGDK & 14.12015 & 12 & 0.2931 \\
LOGR & 14.09760 & 12 & 0.2945 \\
ALL & 39.09865 & 36 & 0.3324 \\
\hline \multicolumn{5}{c}{ Bağımlı değişken: BİST } \\
\hline Excluded & Chi-sq & Df & Prob. \\
LOGBTC & 16.13595 & 12 & 0.1851 \\
LOGDK & 25.89979 & 12 & 0.0111 \\
\hline
\end{tabular}

\begin{tabular}{cccc}
\hline LOGR & 14.83520 & 12 & 0.2506 \\
ALL & 63.02958 & 36 & 0.0035 \\
\hline \multicolumn{4}{c}{ Bağımlı değişken: DK } \\
\hline Excluded & Chi-sq & Df & Prob. \\
LOGBTC & 12.81092 & 12 & 0.3829 \\
LOGBIST & 12.82174 & 12 & 0.3821 \\
LOGR & 14.77390 & 12 & 0.2540 \\
ALL & 38.03438 & 36 & 0.3769 \\
\hline \multicolumn{5}{c}{ Bağıml değişken: $\mathrm{R}$} \\
\hline LOGBTC & 18.49185 & 12 & 0.1016 \\
LOGBIST & 12.59288 & 12 & 0.3993 \\
LOGDK & 32.19219 & 12 & 0.0013 \\
ALL & 74.29373 & 36 & 0.0002 \\
\hline
\end{tabular}

Tablo 9'daki sonuçlar incelendiğinde, döviz kurundan faiz ve BİST'e doğru tek yönlü bir nedensellik ilișkisi tespit edilmiştir. Ayrıca döviz kuru, BTC ve faiz bağımsız değişkenleri birlikte BİST'in nedeni ve döviz kuru, BİST ve BTC değişkenleri birlikte bağımlı değişkeninin nedenidir. Sonuç olarak Türkiye'de döviz kuru, Borsa İstanbul Endeksi ve faiz değişkenleri ile Bitcoin arasında herhangi bir nedensellik ilişkisi tespit edilememiştir.

\subsubsection{Etki-Tepki Grafikleri}

Etki-tepki grafikleri serilere verilen bir şoktan diğerlerinin ne yönde etkilendiğini görmek için oluşturulmaktadır. Her bir seri için etki tepki grafikleri 14 dönem (period) boyunca yapılmıştır. Burada veriler haftalık olarak alındığ 1 için dönem hafta olarak açıklanmaktadır.

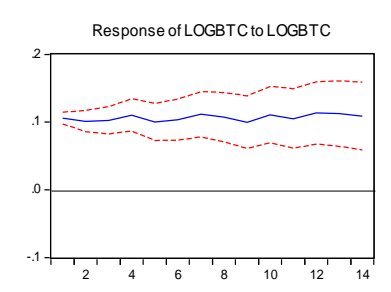

Response to Cholesky One S.D. Innov ations \pm 2 S.E.
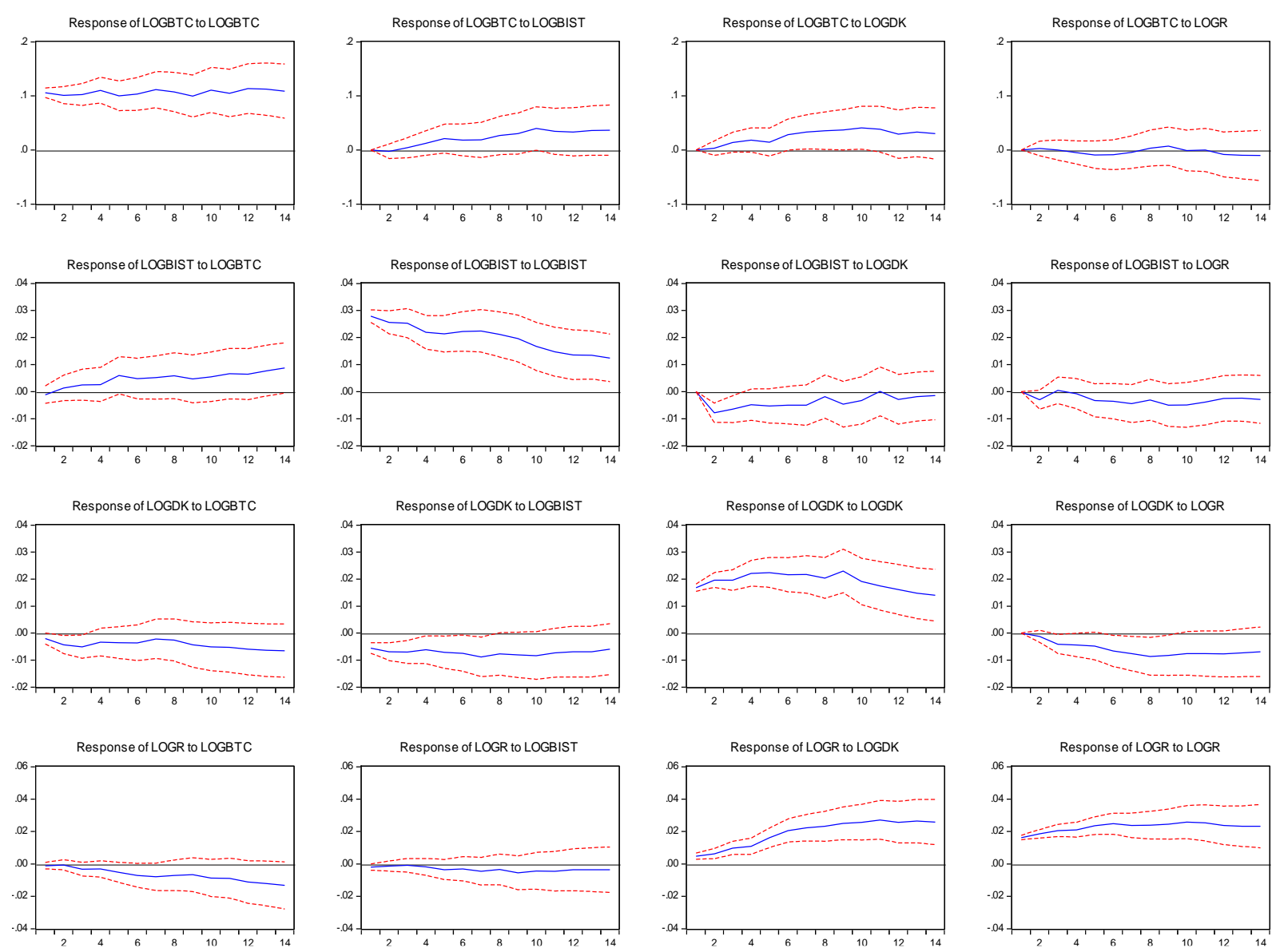

Şekil 4. Etki-Tepki Grafikleri 
Şekil 4'te Bitcoin, döviz kuru ve BİST 100 Endeksi ve faiz değişkenlerinin kendilerine ve birbirlerine olan etkilerini gösteren etki tepki grafikleri görülmektedir. Her bir grafikte düz yatay çizgi sıfır çizgisi olarak adlandırılmaktadır. $\mathrm{Bu}$ sıfır çizgisi tepkinin yok olduğu çizgidir. Sıfır çizgisinin üst tarafı tepkinin pozitif olduğu bölgeyi, altı ise tepkinin negatif olduğu bölgeyi temsil etmektedir. Grafiklerde görülen iki kesikli kırmızı eğriler \%95 güven aralığının alt ve üst sınırlarını, mavi çizgi ise tepki eğrisi olarak adlandırılmaktadır. Yatay çizgi yani sıfır çizgisi eğer bu güven aralığının içerisinde kalması durumunda değişkenlerin tepkileri anlamlı olmamaktadır.

- Grafikte her bir değişkene verilen bir şok değişkenlerin kendilerini ilk haftadan itibaren pozitif ve anlamlı olarak etkilemektedir.

- Bitcoin'e verilen bir şoka BİST 100 Endeksi ve faizin verdiği tepki ilk haftadan itibaren anlamsız iken, döviz kuru üç hafta negatif tepki vermiştir.

- BİST 100 Endeksine verilen bir şoka, Bitcoin ve faizin ilk haftadan itibaren verdiği tepki anlamsız iken, döviz kuru yaklaşık altı hafta negatif tepki vermiştir.

- Döviz kuruna verilen bir şoka, Bitcoin'in verdiği tepki anlamsız iken, BİST 100 Endeksi yaklaşık dört hafta negatif, faiz ise ilk haftadan itibaren pozitif tepki vermiştir.

- Faize verilen bir şoka, Bitcoin ve BİST 100 Endeksinin verdiği tepki anlamsız iken, döviz kuru 10 hafta negatif tepki vermiştir.

\subsubsection{Varyans Ayrıştırma}

Etki-tepki grafikleri, serilerin verilen şoklara karşı tepkilerinin yönü hakkında bilgi verirken varyans ayrıştırması ile göreceli olarak toplam değişimin dönemler boyunca seriler tarafindan nasıl paylaşıldığını göstermektedir. Burada etki tepki grafiklerinde olduğu gibi varyans ayrıştırma 14 dönem (period) boyunca yapılmış ve veriler haftalık olarak alındığı için dönem hafta olarak açıklanmaktadır.

Tablo 10. Bitcoin Varyans Ayrıştırması

\begin{tabular}{cccccc}
\hline Period & S.E. & LOGBTC & LOGBIST & LOGDK & LOGR \\
\hline 1 & 0.105828 & 100.0000 & 0.000000 & 0.000000 & 0.000000 \\
2 & 0.146429 & 99.88803 & 0.026517 & 0.047858 & 0.037596 \\
3 & 0.179430 & 99.25283 & 0.071696 & 0.650193 & 0.025282 \\
4 & 0.211922 & 98.29862 & 0.408040 & 1.223853 & 0.069484 \\
5 & 0.235958 & 97.30901 & 1.115853 & 1.366856 & 0.208286 \\
6 & 0.259949 & 95.97574 & 1.423400 & 2.310305 & 0.290557 \\
7 & 0.285436 & 94.84731 & 1.605791 & 3.283609 & 0.263293 \\
8 & 0.308178 & 93.47581 & 2.136609 & 4.150122 & 0.237464 \\
9 & 0.327480 & 92.02385 & 2.752501 & 4.966972 & 0.256682 \\
10 & 0.350401 & 90.38093 & 3.688735 & 5.705037 & 0.225302 \\
11 & 0.369442 & 89.39212 & 4.187428 & 6.217772 & 0.202678 \\
12 & 0.389047 & 89.09853 & 4.506753 & 6.166883 & 0.227837 \\
13 & 0.407978 & 88.60699 & 4.868453 & 6.263077 & 0.261484 \\
14 & 0.424971 & 88.18937 & 5.226069 & 6.284381 & 0.300176 \\
\hline
\end{tabular}

Bitcion değişkeni için varyans ayrıştırması sonuçları boyunca fazla değişmemiş stabilize olmuştur. Dolayısıyla incelendiğinde ilk hafta Bitcoindeki toplam değişimin $\% 100$ 'ü değișkenin kendisi tarafından açıklanmaktadır. Bu oran Bitcoin değişkeninin en dişsal değişken olduğunun göstergesidir. 11. Haftadan sonra Bitcoin'deki değişimin yaklaşık \%89.4'ü değişkenin kendisi, \%6.2'si ise döviz kuru tarafından açıklanmış ve bu oran diğer haftalar bu iki değişkenin toplam değişkenliği açıklama yönünden birbirine olan etkileri 11 hafta sürmektedir. 14. haftaya gelindiğinde ise Bitcoin'deki değişimin \%88.18'i değişkenin kendisi tarafından, \%5.22'si BİST tarafından ve yaklaşık \%6.28'i de döviz kuru tarafından ve 0.3 'ü ise faiz tarafından açıklanmaktadır.

Tablo 11: Döviz Kurunun Varyans Ayrıştırması

\begin{tabular}{cccccc}
\hline Period & S.E. & LOGBTC & LOGBIST & LOGDK & LOGR \\
\hline 1 & 0.017810 & 1.284356 & 9.695129 & 89.02051 & 0.000000 \\
2 & 0.027770 & 2.926214 & 10.24313 & 86.62383 & 0.206821 \\
3 & 0.035326 & 3.868039 & 10.31776 & 84.33070 & 1.483506 \\
4 & 0.042509 & 3.300390 & 9.242761 & 85.35038 & 2.106468 \\
5 & 0.048951 & 3.014791 & 9.090036 & 85.35558 & 2.539598 \\
6 & 0.054552 & 2.866605 & 9.193031 & 84.40768 & 3.532680 \\
7 & 0.059916 & 2.507767 & 9.825149 & 83.12527 & 4.541815 \\
8 & 0.064401 & 2.335215 & 9.951289 & 81.99017 & 5.723324 \\
9 & 0.069486 & 2.390259 & 9.908533 & 81.38134 & 6.319863 \\
10 & 0.073109 & 2.647442 & 10.25157 & 80.32144 & 6.779550 \\
11 & 0.076098 & 2.931427 & 10.38585 & 79.42713 & 7.255602 \\
12 & 0.078699 & 3.316517 & 10.47613 & 78.45816 & 7.749188 \\
13 & 0.080945 & 3.752891 & 10.62552 & 77.48075 & 8.140833 \\
14 & 0.082909 & 4.195166 & 10.64407 & 76.70665 & 8.454119 \\
\hline
\end{tabular}


Döviz kuru değişkenine ait varyans ayrıştırma sonuçlarına göre ilk hafta döviz kurundaki toplam değişimin \%89'u değişkenin kendisi tarafından, yaklaşık \%9.7'i BİST tarafından, yaklaşık \%1.3'u ise Bitcoin tarafından açıklanmaktadır. Son haftaya gelindiğinde döviz kuru değişkeninin \%76,7'si değişkenin kendisi tarafından, yaklaşık \%4,2'si Bitcoin tarafından, \%10,65'i BİST tarafından, \%8,45'i ise faiz tarafından açıklanmaktadır.

Tablo 12: BİST 100 Endeksi Varyans Ayrıştırması

\begin{tabular}{cccccc}
\hline Period & S.E. & LOGBTC & LOGBIST & LOGDK & LOGR \\
\hline 1 & 0.027942 & 0.167401 & 99.83260 & 0.000000 & 0.000000 \\
2 & 0.038852 & 0.203572 & 95.14962 & 4.037648 & 0.609156 \\
3 & 0.046901 & 0.429776 & 94.44943 & 4.692631 & 0.428159 \\
4 & 0.052062 & 0.596015 & 94.36434 & 4.669730 & 0.369915 \\
5 & 0.056929 & 1.607807 & 92.97916 & 4.778353 & 0.634675 \\
6 & 0.061613 & 1.979599 & 92.38915 & 4.750491 & 0.880757 \\
7 & 0.066125 & 2.333774 & 91.75841 & 4.691235 & 1.216576 \\
8 & 0.069763 & 2.801749 & 91.62568 & 4.285276 & 1.287298 \\
9 & 0.072945 & 2.978276 & 91.04240 & 4.329589 & 1.649737 \\
10 & 0.075264 & 3.319180 & 90.43976 & 4.261013 & 1.980045 \\
11 & 0.077077 & 3.907449 & 89.88389 & 4.062995 & 2.145670 \\
12 & 0.078625 & 4.426362 & 89.37105 & 4.037762 & 2.164823 \\
13 & 0.080208 & 5.182218 & 88.71722 & 3.932030 & 2.168533 \\
14 & 0.081698 & 6.129529 & 87.83120 & 3.823252 & 2.216015 \\
\hline
\end{tabular}

Borsa İstanbul Endeksine ait varyans ayrıştırma sonuçlarına göre ise ilk hafta BİST'teki toplam değişiminin yaklaşık \%99.8'i değişkenin kendisi tarafından açıklanmaktadır. On dördüncü haftanın sonunda ise BISST'teki toplam değişimin tarafından, yaklaşık \%6.13'ü Bitcoin tarafından ve \%2.22'si faiz tarafından açıklanmaktadır. Burada haftalar geçtikçe Bitcoin ve faiz değişkenlerinin açıklama payı haftalar geçtikçe artmakta iken döviz kuru değişkeninin payı azalmaktadır.

Tablo 13: Faiz Varyans Ayrıştırması

\begin{tabular}{cccccc}
\hline Period & S.E. & LOGBTC & LOGBIST & LOGDK & LOGR \\
\hline 1 & 0.017117 & 0.452383 & 1.295708 & 7.939462 & 90.31245 \\
2 & 0.026083 & 0.257909 & 0.850314 & 9.231864 & 89.65991 \\
3 & 0.034827 & 1.034339 & 0.541296 & 13.11840 & 85.30596 \\
4 & 0.042303 & 1.258887 & 0.567225 & 15.51562 & 82.65827 \\
5 & 0.051478 & 1.872717 & 0.847623 & 20.33755 & 76.94211 \\
6 & 0.061227 & 2.676967 & 0.843085 & 25.64907 & 70.83088 \\
7 & 0.069943 & 3.342526 & 1.072538 & 29.76544 & 65.81949 \\
8 & 0.077859 & 3.524026 & 1.056885 & 32.90269 & 62.51639 \\
9 & 0.085847 & 3.493824 & 1.285136 & 35.59704 & 59.62400 \\
10 & 0.093769 & 3.800406 & 1.291819 & 37.37535 & 57.53242 \\
11 & 0.101344 & 4.019907 & 1.302924 & 39.19976 & 55.47741 \\
12 & 0.107865 & 4.625070 & 1.263855 & 40.28819 & 53.82289 \\
13 & 0.114170 & 5.256284 & 1.227329 & 41.32214 & 52.19425 \\
14 & 0.120136 & 5.965884 & 1.200468 & 41.93285 & 50.90080 \\
\hline
\end{tabular}

Faiz değişkenine ilişkin varyans ayrıştırma tablosu ise Tablo 13'de verilmiştir. İlk hafta faizdeki toplam değișimin yaklaşık \%90.3'ü değişkenin kendisi tarafından, \%8.93'ü döviz kuru tarafından, \%1.29'u BİST tarafindan, \%0.45'i ise Bitcoin tarafından açıklanmaktadır. Haftalar geçtikçe faizdeki toplam değişimin açıklama payı azalmış döviz kuru değişkeninin ise payı artmıştır yani faizdeki değişimin büyük bir kısmı döviz kuru tarafından açıklanmaktadır.

\section{Sonuç ve Öneriler}

$\mathrm{Bu}$ konuda yapılan benzer çalışmalara bakıldığında Bitcoin ile ülkelerin borsa endeksleri ve döviz kurları arasındaki ilişkiler ele alınmış ve Bitcoin'in bu değişkenlerle aralarındaki kısa ve uzun dönem ilişskileri tespit edilmiştir.

$\mathrm{Bu}$ çalışmada ise Bitcoin, Borsa İstanbul Endeksi, dolar kuru ve faiz arasındaki ilişkiler VAR modeli ile analiz edilmiştir. VAR analizine göre Bitcoin'e verilen bir şoka döviz kuru üç hafta negatif tepki vermiştir. Ayrıca BIST
100 Endeksine verilen bir şoka, döviz kuru yaklaşık altı hafta negatif tepki, döviz kuruna verilen bir şoka ise BİST 100 Endeksi yaklaşık dört hafta negatif, faiz ise ilk haftadan itibaren pozitif tepki vermiştir. Faize verilen bir şoka, döviz kuru yaklaşı 10 hafta negatif tepki vermiştir. Eşbütünleşme testi sonucuna göre bu değişkenler arasında uzun dönemde herhangi bir ilişki tespit edilememiștir. Nedensellik testi sonuçlarına göre de döviz kuru, BİST100 ve faiz değişkenleri Bitcoin'in nedeni olmamaktadır.

Kripto paralar içinde işlem hacmi en büyük olan Bitcoin'e Türkiye açısından bakıldığında belirli bir farkındalığın olduğu ancak bu farkındalığın uzun vadeli yatırım boyutunda ve makro değişkenleri etkileyebilecek güçte olmadığı görülmektedir. Ancak kısa vadede sadece döviz kuru üzerinde bir negatif etkisi olduğu gözükmektedir. Türkiye yeni sayılabilecek olan bu teknolojinin yaygınlaşabilmesi için belirli bir zamana ihtiyaç vardır. 
Kripto paralar ile yapılacak olan gelecekteki çalışmalar için iki yaklaşım önerilmektedir. İlk olarak Bitcoin fiyatlarındaki artış ve azalış trendlerinin kalıcı olup olmadığı ya da zaman içerisinde bozulup bozulmadığını görebilmek için çalışmalar farklı zaman dilimleri için tekrarlanabilir. İkinci olarak çalışmalara daha çok kripto para ve finansal makro değişkenler eklenerek aralarındaki ilişkilerin boyutu genişletilebilir.

\section{Kaynakça}

Ağan, B. ve Aydın, Ü. (2018). Kripto Para Birimlerinin Küresel Etkileri: Asimetrik Nedensellik Analizi, https://www.researchgate.net/publication/328278747 _Kripto_Para_Birimlerinin_Kuresel_Etkileri_Asime trik_Nedensellik_Analizi (Erişim Tarihi: 26.10.2019)

Andersson, G. ve Wegdell, A. (2014). Prospects of Bitcoin: An Evaluation of Its Future, Lund University Master Thesis, Sweden.

Aslan, A. (2018). Kripto Para Olgusu ve Blockchain Teknolojisi: Ekonomik Aktörlerin Tepkisi, Maliyet Analizi, VAR Modeli ve Granger Nedensellik Testi, Yayınlanmış Yüksek Lisans Tezi, Hacettepe Üniversitesi Sosyal Bilimler Enstitüsü, Ankara.

Ateş, B. A. (2016). Kripto Para Birimleri, Bitcoin ve Muhasebesi, Çankırı Karatekin Üniversitesi, Sosyal Bilimler Enstitüsü Dergisi, 7(1), 349-366.

Atik, M., Köse, Y., Yılmaz, B. ve Sağlam, F. (2015). Kripto Para: Bitcoin ve Döviz Kurları Üzerine Etkileri, Bartın Üniversitesi İ.I.B.F. Dergisi, 6(11), 247-261.

Baur, D. G., Dimpel, T. ve Kuck, K. (2018). Bitcoin, Gold and The US Dollar - A Replication and Extension, Finance Research Letters, 25, 103-110.

Bhattacharjee, S. (2016). A Statistical Analysis of Bitcoin Transactions During 2012 to 2013 In Terms of Premier Currencies: Dollar, Euro and Rubles, Vidwat, The Indian Journal of Management, 1-5.

Chu, J., Nadarajah, S. ve Chan, S. (2015). Statistical Analysis Of The Exchange Rate Of Bitcoin, Plos One, 10 (7), 1-27.

Çeker, S.M. (2018). Kripto Paralar ve Ekonomik Etkileri, Ylldız Teknik Üniversitesi, Íktisadi ve İdari Bilimler Fakültesi, İktisat Bölümü, Yayınlanmış Bitirme Tezi, İstanbul.

Çütçü, İ. ve Kılıç, Y. (2018). Bitcoin Fiyatları İle Borsa İstanbul Endeksi Arasındaki Eşbütünleşme ve Nedensellik ilişkisi, Eskişehir Osmangazi Üniversitesi İ̈BF Dergisi, 13(3), 235-250.

Çütçü, İ. ve Kılıç, Y. (2018). Bitcoin Fiyatları İle Dolar Kuru Arasındaki İlişki: Yapısal Kırılmalı Zaman Serisi Analizi, Yönetim ve Ekonomi Araştırmaları Dergisi, 16(4), 349-366.

Dağlı, İ. (2019). Kripto Paraların Dünya Ekonomisindeki Makroekonomik Boyutu ve Türk Lirası Bazında Yatırım-Tasarruf Aracı Olarak Kripto Paralara
Genel Bir Bakıș, Uygulamall Ekonomi ve Sosyal Bilimler Dergisi, 1(1), 40-49.

Dai, W. (1998), B-money, http://www.weidai.com/bmoney.txt, (Erişim Tarihi: 30.10.2019).

Dirican, C. ve Canöz, İ. (2017). Bitcoin Fiyatları İle Dünyadaki Başlıca Borsa Endeksleri Arasındaki Eşbütünleşme İlişkisi: ARDL Modeli Yaklaşımı İle Analiz, Journal of Economics, Finance and Accounting, 4(4), 377-392.

Durbilmez S.E. ve Türkmen, Y.E. (2019). Blockchain Teknolojisi Ve Türkiye Finans Sektöründeki Durumu, Finans Ekonomi ve Sosyal Araştırmalar Dergisi, 4(1), 30-45.

Dyhberg, A. H. (2016). Bitcoin, Gold and The Dollar - A GARCH Volatility Analysis, Finance Research Letters, 16, 85-92.

European Central Bank (Ecb), (2012). Virtual Currency Schemes,

https://www.ecb.europa.eu/pub/pdf/other/virtualcurr encyschemes201210en.p-df, (Erişim Tarihi: 02.11.2019).

Fallahpour, M., Shirmohammadi, S., Semsarzadeh, M., \& Zhao, J. (2014). Tampering detection in compressed digital video using watermarking. IEEE Transactions on Instrumentation and Measurement, 63(5), 1057-1072.

Financial Action Task Force (Fatf), (2014). Virtual Currencies: Key Definitions and Potential AML/CFT Risks, http://www.fatfgafi.org/media/fatf/documents/reports/Virtualcurrency-key-definitions-and-potential-aml-cftrisks.pdf, (Erişim Tarihi: 02.11.2019).

Georgoul, I., Pournarakis, D., Bilanakos C., Sotiropoulos, D.N., Giaglis, G.M. (2015). Using Time-Series and Sentiment Analysis to detect the Determinants of Bitcoin Prices, SSRN: https://ssrn.com/abstract=2607167 http://dx.doi.org/10.2139/ssrn.2607167.

Granger, C.W (1969). Investigating Casual Relations by Ecoometric Models and Cross-Spectral Methods, Econometrica, Journal of the econometric society, 424-438.

Güleç, Ö.F., Çevik, E. ve Bahadır, N. (2018). Bitcoin İle Finansal Göstergeler Arasındaki İlişkinin İncelenmesi, Klrklareli Üniversitesi İktisadi ve İdari Bilimler Fakültesi Dergisi, 7(2), 18-37.

Halving 101: Bitcoin Halving Ne Demek? Bitcoin Blok Ödülü Yarlanmasl Nedir? (2020), https://tr.investing.com/news/cryptocurrencynews/halving-101-bitcoin-halving-ne-demekbitcoin-blok-dulu yarlanmas-nedir-1952916, (Erişim Tarihi: 17.06.2020).

Herbert, J. \& Litchfield, A. (2015). A Novel Method for Decentralised Peer-to-Peer Software License Validation Using Cryptocurrency Blockchain 
Technology, 38th Australian Computer Science Conference (ACSC), 27-35.

İçellioğlu, C.Ş ve Öztürk, M. B. E. (2017). Bitcoin İle Seçili Döviz Kurları Arasındaki İlişkinin Araştırılması: 2013-2017 Dönemi İçin Johansen Testi ve Granger Nedensellik Testi, Maliye ve Finans Yazıları, (109), 51-70.

Kadılar, C. (2000). Uygulamalı Çok Değişkenli Zaman Serileri Analizi, Hacettepe Üniversitesi, Ankara.

Kanat, E. ve Öget, E. (2018). Bitcoin İle Türkiye Ve G7 Ülke Borsaları Arasındaki Uzun Ve Kısa Dönemli İlişkilerin İncelenmesi, Finans Ekonomi ve Sosyal Araştırmalar Dergisi, 3(3), 601-614.

Karaoğlan, S., Arar, T. ve Bilgin, O. (2018). Türkiye'de Kripto Para Farkındalığı ve Kripto Para Kabul Eden İşletmelerin Motivasyonları, Işsletme ve İktisat Çalışmaları Dergisi, 6(2), 15-28.

Katsiampa, P. (2017). Volatility Estimation For Bitcoin: A Comparison of GARCH Models, Economics Letters, 158, 3-6.

Kesebir, M. ve Günceler, B. (2019). Kripto Para Birimlerinin Parlak Geleceği, I Ĭdır Üniversitesi Sosyal Bilimler Dergisi, No. 17: 605-625.

Khalılov, M.C.K., Gündebahar, M., Kurtulmuşlar, İ., (2017). Bitcoin ile Dünya ve Türkiye'deki Dijital Para Çalışmalarl Üzerine Bir Inceleme, 19. Akademik Bilişim Konferansı, 8-10 Şubat 2017, Aksaray.

Klein, T., Thu, H. P., Walther, T. (2018). Bitcoin is Not The New Gold-A Comparison of Volatility, Correlation, And Portfolio Performance, International Review of Financial Analysis, 59, 105116.

Koçoğlu, Ş., Çevik, Y. E. ve Tanrı̈ven, C. (2016). Bitcoin Piyasalarının Etkinliği, Likiditesi ve Oynaklığı, Işletme Araştırmaları Dergisi, 8 (2), 77-97.

Kristoufek, L. (2015). What Are The Main Drivers Of The Bitcoin Price? Evidence From Wavelet Coherence Analysis, Plos One, 10(4), 1-19.

Lemieux, V. L. (2016). Trusting records: Is blockchain technology the answer? Records Management Journal, 26(2), 110-139.

Mert, M. ve Çağlar, E. A. (2019). Eviews Ve Gauss Uygulamall Zaman Serileri Analizi, Detay Yayıncilık, Ankara.

Min, H. (2019). Blockchain technology for enhancing supply chain resilience, Business Horizons, 62(1), 35-45.
Miraz, M.H., ve Ali, M. (2018). Applications of Blockchain Technology beyond Cryptocurrency, Annals of Emerging Technologies in Computing (AETiC), 2 (1), 1-6.

Nair, J., ve Motwani, D. A. (2018). Crypto Currency: Bubble or Boom, International Journal of Advance Research in Computer Science and Management Studies, 6(1), 35-42.

Nakamoto, S. (2008). Bitcoin: A Peer-to-Peer Electronic Cash System, http://www.bitcoin.org/bitcoin.pdf (Erişim Tarihi: 30.10.2019).

Satoshi Nedir? (2020), https://kriptokoin.com/satoshi-nedir/ (Erişim Tarihi: 20.06.2020)

Sims, C. (1980). Macroeconomics And Reality, Econometrica, 48, 1-48.

Song, Y. (2016). A Study of Bitcoin Price's Relationship With Local Currency Exchange Rate and Stock Market Index in Emerging Economies Using VECM, ETD Collection for Fordham University.AAI10246887,

https://fordham.bepress.com/dissertations/AAI10246 887.

Szetela, B., Mentel G. ve Gedek S. (2016). Dependency Analysis between Bitcoin and Selected Global Currencies, Dynamic Econometric Models, 16, 133144.

Topaloğlu, E.A. (2019). Kripto Para Bitcoin ve Döviz Kurları İlişkisi: Yapısal Kırılmalı Eşbütünleşme ve Nedensellik Analizi, CBÜ Sosyal Bilimler Dergisi, 17(2), 367-382.

Turan, Z. (2018). Kripto Paralar, Bitcoin, Blokchain, Petro Gold, Dijital Para ve Kullanım Alanları, Ömer Halisdemir Üniversitesi İktisadi ve İdari Bilimler Fakültesi Dergisi, 11(3), 1-5.

Vishnumurthy, V., Chandrakumar, S. ve Sirer, E.G. (2005). KARMA: A Secure Economic Framework for Peerto-Peer Resource Sharing, Department of Computer Science, Cornell University, Ithaca, NY 14853.

Yıldırım, H. (2018). Günlük Bitcoin İle Altın Fiyatları Arasındaki İlișkinin Test Edilmesi: 2012-2013 Yılları Arası Johansen Eşbütünleşme Testi, Insan ve Toplum Bilimleri Araştırmaları Dergisi, 7(4), 23282343.

Zheng, Z., Xie, S., Dai, H.N., Chen, X., Wang, H., (2018). Blockchain challenges and opportunities: a survey, Int. J. Web and Grid Services, 14(4), 352-375.

https://coin-turk.com/, (Erişim Tarihi: 01.11.2019).

https://tr.investing.com/crypto/bitcoin/btc-usd-historicaldata, (Erişim Tarihi: 28.10.2019). 